DOI: 10.34015/2523-4552.2019.3.20

удк 343.8

Колб О. Г.,

доктор юридичних наук, професор, професор кафедри кримінального права та процесу Національного університету «Львівська політехніка» ORCID ID: 0000-0003-1792-4739

Махніцький O. I., аспірант кафедри кримінального права та процесу Східноєвропейського національного університету імені Лесі Українки

\title{
ЗМІСТ ГРОМАДСЬКОГО КОНТРОЛЮ У СФЕРІ ВИКОНАННЯ ПОКАРАНЬ УКРАЇНИ
}

У статті визначено сутність, зміст і стан громадського контролю у сфері виконання покарань України, а також встановлені найбільш суттєві проблеми його реалізації на практиці та розроблені деякі науково обгрунтовані заходи, спрямовані на удосконалення правового механізму з цих питань.

Ключові слова: контроль; громадськість; сфера виконання покарань; правові засади; громадський контроль.

В статье определена сущность, содержание и состояние общественного контроля в сфере исполнения наказаний Украины, а также установлены наиболее существенные проблемы его реализации на практике и разработаны некоторые научно обоснованные мероприятия, направленные на совершенствование правового механизма по этим вопросам.

Ключевые слова: контроль; общественность; сфера исполнения наказаний; правовые основы; общественный контрольй.

Постановка проблеми. Вивчення змісту кримінальновиконавчого законодавства України (ст. 2 КВК) показало, що у його нормах термін «громадськість», як ключовий елемент у словосполученні «громадський контроль», вживається у такому контексті:

1) як завдання даного законодавства - у виді участі громадськості в процесі контролю за виконанням кримінальних покарань (ч. 2 ст. 1 КВК);
2) як принцип кримінальновиконавчого законодавства, виконання покарань - у виді участі громадськості в передбачених законом випадках у діяльності органів і установ виконання покарань (ст. 5 КВК, ст. 2 Закону України «Про Державну кримінально-виконавчу службу України»);

3) як один із основних засобів виправлення і ресоціалізації засуджених - у виді громадського впливу (ч. 3 ст. 6 КВК); 
4) як одне з прав засуджених у виді права на звернення до громадських об'єднань (ч. 1 ст. 8 КВК);

5) як один із суб'єктів відвідування установ виконання покарань (ч. 1 ст. 24 КВК);

6) як суб'єкт громадського контролю за дотриманням прав засуджених під час виконання кримінальних покарань в установах виконання покарань (виправних колоніях, арештних домах, виправних центрах та слідчих ізоляторах) - у виді спостережних комісій (ч. 2 ст. 25 КВК);

7) як самодіяльні організації засуджених до позбавлення волі (ст. 127 КВК; ст. 27 Закону України «Про Державну кримінально-виконавчу службу»);

8) як суб'єкт здійснення богослужіння та релігійних обрядів у колоніях (ст. 128, 128-1 КВК) - у виді душпастирської опіки засуджених;

9) як учасники виправлення та ресоціалізації засуджених неповнолітніх (ст. 149 КВК);

10) як суб'єкт нагляду за поведінкою осіб, звільнених від відбування покарання 3 випробуванням (ч. 2 ст. 163 КВК);

11) як учасник дисциплінарної комісії установи виконання покарань - у формі запрошення на її засідання (ч. 3 ст. 135 КВК);

12) як суб'єкти взаємодії з органами та установами виконання покарань - у виді сприяння їм у виконанні визначених у законі завдань (ст. 5, 20 Закону України «Про Державну кримінально-виконавчу службу»);

13) як суб'єкт демократичного цивільного контролю (Закон України «Про демократичний цивільний контроль над Воєнною організацією i правоохоронними органами»).
Здавалось би, в Україні створений належний правовий механізм для здійснення громадського контролю у сфері виконання покарань. Проте, як засвідчили результати даного наукового дослідження, на практиці ці питання не в повній мірі кореспондується із зазначеними вище формами і видами діяльності громадськості, пов'язаної з виконанням і відбуванням кримінальних покарань.

Постановка завдання. Виходячи 3 вищевикладеного, основним завданням даної наукової статті $\epsilon$ розробка науково обгрунтованих заходів, пов'язаних із з'ясування змісту та сутності громадського контролю у сфері виконання покарань, а також розробка на цій підставі відповідних шляхів, що стосуються удосконалення правового механізму 3 цих питань.

Аналіз останніх досліджень і публікацій. Як показало вивчення наукової літератури, досить активно займаються розробкою питань, що стосуються сутності змісту громадського контролю у сфері виконання покарань України в контексті визначених у законі підстав такої діяльності, такі науковці: К. А. Автухов, В. А. Бадира, І. Г. Богатирьов, В. В. Василевич, Б. М. Головкін, О. М. Гумін, О. М. Джужа, I. О. Колб, В. О. Меркулова, В. Я. Конопельський, В. Л. Ортинський, А. Х. Степанюк, В. М. Трубников, І. С. Яковець та ін.

Поряд з цим, слід визнати, що у сучасних умовах реформування сфери виконання покарань проблеми, які мають пряме відношення до даного предмету дослідження, а також заходи щодо удосконалення правового механізму з означеної тематики досліджені не в повній мірі, а тому 
тема цієї наукової статті є досить актуальною та такою, що має теоретичне і практичне значення.

Виклад основного матеріалу Як встановлено в ході даного дослідження, у сучасній історії України прийнято ряд важливих у цьому сенсі заходів, які мають пряме відношення до досліджуваної у даній роботі проблематики та створили належне правове підгрунтя для участі громадськості, поряд з Уповноваженим Верховної Ради України та прокурором, в процесі контролю за діяльністю персоналу органів та установ виконання покарань, а також інших правоохоронних органів. Зокрема, у Законі України «Про Національну поліцію» $\epsilon$ спеціальний розділ VIII «Громадський контроль поліції», в якому закріплено положення про те, що 3 метою інформування громадськості про діяльність поліції керівник поліції та керівники територіальних органів поліції раз на рік готують та опубліковують на офіційний веб-портал органів поліції звіт про діяльність поліції (ч. 1 ст. 86). Більш того, керівники територіальних органів поліції зобов'язані регулярно оприлюднювати дані про вжиті заходи щодо виявлення, запобігання та припинення порушень публічного порядку на офіційних веб-порталах органів, які вони очолюють (ч. 3 ст. 86 даного Закону).

I, що найцінніше у цьому Законі - за результатами оцінки діяльності територіального органу поліції Верховна Рада України або відповідні ради місцевих депутатів можуть прийняти резолюцію недовіри керівнику відповідного органу (підрозділу) поліції, що є підставою для звільнення його із займаної посади (ст. 87). Крім цього, відповідно до вимог ст. 90 Закону України «Про Національну поліцію», контроль за діяльністю поліції може здійснюватися у формі залучення представників громадськості до спільного розгляду скарг та дії чи бездіяльності поліцейських та до перевірки інформації про належне виконання покладених на них обов'язків згідно до законів та інших нормативноправових актів України.

На сьогодні, як встановлено в ході даного дослідження, у жодному законі та іншому правовому джерелі, що стосується сфери виконання покарань та, зокрема, діяльності персоналу органів і установ виконання покарань України, не закріплено зазначених вище у Законі України «Про Національну поліцію» положень.

Нічого з цього приводу не сказано й у Концепції реформування (розвитку) пенітенціарної системи України, а також в інших державних програмах (Національній стратегії у сфері прав людини; стратегії реформування судоустрою, судочинства та суміжних правових інститутів на 2015-2020 рр.; стратегії сталого розвитку «Україна - 2020»; ін.).

$\mathrm{He}$ запропоновані зазначені норми й в проекті Закону «Про пенітенціарну систему», хоча їх наявність, виходячи 3 існуючого стану справ у сфері виконання покарань України, є вкрай необхідною.

Як показали результати даного дослідження, фундаментальні засади громадського контролю визначені в Законі України «Про демократичний цивільний контроль над Воєнною організацією і правоохоронними органами держави» [1]. Зокрема, у ст. 1 даного Закону закріплено зміст поняття «демократичний цивільний контроль над Воєнною організацією 
та правоохоронними органами держави» (цивільний контроль), під яким слід розуміти комплекс здійснюваних відповідно до Конституції і законів України правових, організаційних, інформаційних заходів для забезпечення неухильного дотримання законності й відкритості в діяльності всіх складових частин Воєнної організації та правоохоронних органів держави, сприяння їхній ефективній діяльності і виконанню покладених на них функцій, зміцненню державної та військової дисципліни.

Важливим також, у контексті змісту предмета даного наукового пошуку, $є$ й встановлені у цьому Законі основні завдання цивільного контролю (ст. 2), а саме:

1) спрямування діяльності органів та установ виконання покарань на реалізацію визначених засадами внутрішньої і зовнішньої політики завдань у сфері правоохоронної діяльності з метою зміцнення національної безпеки та громадського порядку;

2) дотримання законності в діяльності органів та установ виконання покарань;

3) створення умов, які унеможливлюють використання військових формувань та інших правоохоронних органів для обмеження прав і свобод засуджених, позбавлених волі;

4) запобігання та недопущення порушень конституційних прав i свобод, захист законних інтересів персоналу органів та установ виконання покарань, осіб, звільнених зі служби (роботи) в ДКВС України, а також членів їхніх сімей;

5) урахування громадської думки, пропозицій громадян та громадських організацій при обгово- ренні й ухваленні рішень з питань діяльності органів та установ виконання покарань та зміцнення громадського порядку і законності у сфері виконання покарань;

6) виділення відповідно до законів у необхідних обсягах і раціональне використання бюджетних коштів, спрямованих на утримання і функціонування органів та установ виконання покарань України;

7) використання за цільовим i функціональним призначенням державного майна, переданого в управління органам та установам виконання покарань;

8) своєчасне, повне і достовірне інформування органів державної влади та суспільства про діяльність органів та установ виконання покарань, забезпечення їі відповідності вимогам Конституції України і законів України, нормам міжнародного права, реальній кримінальній обстановці, громадського порядку.

Виходячи з того, що в чинному кримінально-виконавчому законодавстві України, як форми контролю, що зазначені в Законі України «Про Національну поліцію», так і завдання громадського контролю, мова про які ведеться в Законі України «Про демократичний цивільний контроль над Воєнною організацією і правоохоронними органами держави» [1], не визначені, логічно було б КВК України видозмінити з урахуванням цих положень.

Враховуючи, що у Законі України «Про демократичний цивільний контроль над Воєнною організацією і правоохоронними органами держави» одним із завдань визначено завдання по забезпеченню цивільного контролю з питань відповідності діяльності органів та установ виконання 
покарань Конституції і законам України та нормам літературного права, а також з метою удосконалення правових засад застосування заходів вгамування до засуджених, позбавлених волі, слід також видозмінити КВК України шляхом внесення відповідних змін і доповнень, що пропонуються на науковому рівні [2].

Тільки при такій видозміні громадського контролю у сфері виконання покарань України набуде іншого змісту й практика виконання та відбування покарань, а також діяльність персоналу установ виконання покарань, яка пов'язана із застосування до засуджених основних засобів виправлення та ресоціалізації та на більш високому рівні будуть реалізовуватись визначені в законі завдання, що пов'язані із запобіганням тортурам та нелюдському або такому, що принижує гідність, поводженню із засудженими.

Як у зв'язку з цим зазначили деякі дослідники, повноцінне життя сучасного суспільства передбачає наявність в ньому третього сектора (перший - державний, другий - сектор приватного бізнесу), тобто діяльності громадських організацій та громадського контролю за першими двома секторами [3, с. 28]. При цьому, як встановив Г. О. Радов, проблема стоїть гостріше, ніж здається на перший погляд. I для того, щоб не виявитись в такій ситуації, персонал органів та установ виконання покарань повинен сам ініціювати громадську активність. I, перш за все, - для підтримки самого себе [3, с. 17]. На його переконання (і з цим варто погодитись), лише громадянське суспільство та його інститути можуть осудити персонал, так само, як і можуть його виправдати [3, c. 17].
Важливість видозміни правових засад і змістовних елементів громадського контролю у сфері виконання покарань обумовлена ще й тим, що у чинному кримінальновиконавчому законодавстві України, якщо виходити з вимог ст. 25 КВК, ця форма діяльності громадських організацій по суті зведена до двох його видів:

a) надання допомоги органам та установа виконання покарань у виправленні засуджених і проведенні соціально-виховної роботи (ч. 1 цієї статті Кодексу);

б) здійснення контролю єдиним легітимним органом - спостережними комісіями (ч. 2) [4].

Проте, вивчення змісту Положення про спостережені Комісії, яке затверджено Кабінетом Міністрів України (постанова від 01 квітня 2004 року № 429), показало, що зазначений громадський контроль $\epsilon$ формальним та не стосується суттєвих аспектів кримінально-виконавчої діяльності, зокрема й питань, пов'язаних із застосуванням фізичної сили, спеціальних засобів, гамівної сорочки і зброї до засуджених, позбавлених волі.

Більш того, більшість норм даного Положення не кореспондуються із змістом тих змін і доповнень, які внесені до чинного КВК України на протязі 2005-2018 рр., включаючи й ті, що стосуються приведення умов відбування покарань у виді позбавлення волі до Європейських стандартів, а також з відповідними статтями Закону України «Про демократичний цивільний контроль над Воєнною організацією і правоохоронними органами держави». Так, ні спостережні комісії, ні інші громадські об'єднання не можуть з цих причин 
належним чином реалізовувати у своїй практичній діяльності такі принципи здійснення цивільного контролю в ст. 4 даного Закону, як:

1) розмежування функцій і повноважень політичного керівництва сферою виконання покарань України, особливо в часи Президента України В. А. Ющенка (2005-2010 рр.) та Президента України П. О.Порошенка (2014-2018 рр.), коли центральний орган виконавчої влади, що реалізує державну політику у сфері виконання кримінальних покарань, очолювали представники коаліційних політичних партій, що об'єднались у Верховній Раді України;

2) взаємодії й відповідальності органів держаної влади та органів управління сферою виконання покарань за здійсненням державної політики у справі зміцнення законності й громадського порядку, за своєчасне і всебічне матеріально-фінансове забезпечення органів та установ виконання покарань для реалізації покладених на них функцій (безконтрольність з цих питань сприяла тому, що щорічно, розпочинаючи 3 1991 року по даний час, з Державного бюджету України на сферу виконання покарань виділяється лише 40 \% від їі потреб, а стан повторної та пенітенціарної злочинності і злісних правопорушень залишається незмінним за весь цей період);

3) прозорості видатків на утримання органів та установ виконання покарань (так, як зазначено в розділі II Концепції реформування (розвитку) пенітенціарної системи України 2017 року, за всі часи незалежності ДКВС України фінансувалась у розмірі 40 \% від потреб. При цьому, тільки у 2017 році додаткова потреба у фінансуванні сфери вико- нання покарань становила 730 млн грн (розділ VI Концепції));

4) відкритості для суспільства інформації про діяльність ДКВС України, яка не становить державну таємницю, з урахуванням визначеної законом специфіки державних правоохоронних органів (у той самий час, інформаційний бюлетень центрального органу виконавчої політики, що реалізує державну політику України у сфері виконання покарань, який публікувався з 1991 по 2016 рр., на сьогодні Адміністрацією ДКВС Міністерства юстиції України не випускається);

5) відповідальності посадових осіб за своєчасність, повноту і достовірність інформації, що надається, та реагування на звернення громадян, громадських організацій, виступів засобів масової інформації.

Звичайно, якби громадські організації та інші суб'єкти цивільного контролю, що визначені в ст. 6 Закону України «Про демократичний цивільний контроль над Воєнною організацією і правоохоронними органами держави» більш активно та цивілізовано застосовували визначені у цьому нормативно-правовому акті повноваження та принципи, то, мабуть, дещо по-іншому й мала вигляд ситуація, що склалась, зокрема, у зв'язку із застосуванням до засуджених у місцях позбавлення волі, фізичної сили, спеціальних засобів, гамівної сорочки та зброї, а саме - це має визнаватись громадськістю як надзвичайна подія, позаяк зазначена діяльність персоналу ДКВС України пов'язана 3 суттєвим порушенням прав тих осіб, щодо яких застосовуються встановлені у законі заходи вгамування (право на життя, здоров'я, гідність, безпеку тощо). 
Поряд 3 цим, варто зазначити, що питання громадського контролю мають стати предметом окремого дисертаційного дослідження, враховуючи, на теперішній час його ефективність $\epsilon$ низькою, а результативність низькою. При цьому, однією з обставин, що негативно впливає на стан даної діяльності, $\epsilon$ те, що у чинному кримінально-виконавчому законодавстві України, зокрема в ч. 2 ст. 25 КВК, визначений лише один громадський орган - спостережені комісії, повноваження яких $€$ «куцими» (вузькими та несуттєвими), а форми впливу на адміністрацію УВП - формальними та беззмістовними.

Саме тому, так важливо на законодавчому рівні закріпити реальні правові гарантії реалізації на практиці громадського контролю у сфері виконання покарань, а також принципи та юридичні наслідки такої суспільної діяльності.

Як з цього приводу влучно висловився Г. О.Радов, кримінальновиконавча система без громадських організацій не обійдеться. А тому ми сьогодні не тільки можемо, ми зобов'язані сприяти створенню таких організацій, як необхідної умови, яка забезпечить якісне функціонування нашої системи. Це $€$ категоричний імператив, будь-якої спроби блоку- вати участь громадянського суспільства в діяльності кримінальновиконавчої системи неминуче приведуть до краху системи, беззаперечно підштовхують її у той стан, який відомим є для нас як «ГУЛАГ» [3, c. 12]. При цьому, на його переконання (і варто з цим погодитись у повній мірі), нормативна база 3 цих питань не повинна бути абстрактною, вона має створювати механізми, які дозволяють її реально застосовувати $[3$, c. 23].

Висновки. Таким чином, слід констатувати, що на сьогодні громадський контроль у сфері виконання покарань знаходиться на низькому нормативному рівні, а ті потенційні можливості, які закріплені в законах, що стосуються в цілому цивільного контролю за правоохоронною системою, у реальних кримінально-виконавчих правовідносинах майже не реалізуються. Все це, в кінцевому результаті, не дозволяє виявляти глибинні детермінанти, що пов'язані із формуванням протиправної поведінки засуджених під час відбування кримінальних покарань, з одного боку, а також психологією дій персоналу органів та установ виконання покарань у таких ситуаціях та прийняттям адекватних рішень при цьому, з іншого боку.

\section{Список використаних джерел}

1. Про демократичний цивільний контроль над Воєнною організацією і правоохоронними органами держави : Закон України від 19 червня 2003 року № 975IV. Відомості Верховної Ради Украӥни. 2003. № 46. Ст. 366.

2. Колб I. О. Соціально-правова природа застосування в Україні до засуджених, позбавлених волі, заходів вгамування: монографія. Луцьк : Терен, 2019. 546 с.

3. Тюрьма и общество : материалы семинара для персонала учреждений по исполн. наказ. Донец. области. Донецк : «Донецкий Мемориал», 2000. 116 с.

4. Кримінально-виконавчий кодекс України: прийнятий 11 липня 2003 р. Відомості Верховної Ради України. 2004. № 3-4. Ст. 21. 


\section{References}

1. Kolb, I. O. (2019). Socialno-pravova priroda zastosuvannya v Ukrayini do zasudzhenih, pozbavlenih voli, zahodiv vgamuvannya. Luck: Teren [in Ukrainian].

2. Tyurma i obshestvo (2000). Doneck: «Doneckij Memorial» [in Ukrainian].

O. Kolb, Doctor of Laws, Professor, Professor of the Department of Criminal Law and Process of the Lviv Polytechnic National University

ORCID ID: 0000-0003-1792-4739

o. Makhnitsky, Postgraduate student in the Department of Criminal Law and Procedure Eastern European National University named after Lesya Ukrainka

\section{Content of public control in the sphere of execution of punishments of Ukraine}

The article defines the nature, content and state of public control in the sphere of punishment of Ukraine, as well as identifies the most significant problems of its implementation in practice and develops some scientifically grounded measures aimed at improving the legal mechanism on these issues.

It would seem, in Ukraine the appropriate legal mechanism for implementation of public control in the sphere of execution of punishments is created. However, as showed results of this scientific research, in practice these questions it is not fully corresponded to the forms and types of activity of the public, stated above with performance and serving of criminal penalties.

Proceeding from it, the main objective of this scientific article is development of evidence-based actions, «the relation to with» clearings of contents and essence of public control in the sphere of execution of punishments and also development on this basis of appropriate ways that concern improvement of a legal mechanism on these questions.

It should be noted that at present public control in the sphere of execution of sentences is at a low regulatory level, and those potential opportunities, which are enshrined in the laws concerning in general civil control over the law enforcement system, are hardly realized in real criminal-law relations. All this, in the end, does not allow to identify the deep determinants that are associated with the formation of unlawful behavior of convicts while serving criminal sentences, on the one hand, as well as the psychology of actions of staff and penal institutions in such situations and making adequate decisions when this, on the other hand.

Keywords: control; public; sphere of execution of penalties; legal principles; public control. 